\title{
Identifying Bacterial Communities in a Full-Scale Wood Chip Biofilter
}

\author{
Hakan Çelikten ${ }^{1 *}$, Arslan Saral'², S. Levent Kuzu² \\ ${ }^{1}$ Department of Bioengineering, Kafkas University, Kars, Turkey \\ ${ }^{2}$ Department of Environmental Engineering, Yildiz Technical University, Istanbul, Turkey
}

Received: 17 July 2018

Accepted: 15 October 2018

\begin{abstract}
Although biofilters have an important role in the purification of VOC mixtures or inorganic waste gas compounds and despite their widespread use, the microbial community characterization is not fully known, particularly in full-scale biofiltering processes. Maintaining microbial activity and sustainability are major factors in biological processes such as biofilters, in which the contaminating compounds are catalyzed by the microbial community. In this study, bacterial diversity was investigated in a full-scale biofilter unit, which is operated to treat odorous gases, collected from a composting process. Bacterial strains composition was determined by the DNA isolation of samples taken from wood chips. The wood chips were processed by amplification of $16 \mathrm{~S}$ rDNA by PCR (polymerase chain reaction) and sequencing. The determined nucleotide and translated amino acid sequences were compared with those deposited in the National Center for Biotechnology Information (NCBI) database by a BLASTN search. Bacillaceae (Solibacillus silvestris, Bacillus licheniformis, Bacillus cereus, Bacillus paralicheniformis) and Enterobacteriaceae (Enterobacter cloacae, Enterobacter ludwigii, Serratia marcescens) dominated the bacterial family in the packing material by $53 \%$ and $47 \%$, respectively.
\end{abstract}

Keywords: biofilter; VOC; bacterialcommunity; PCR; sequence

\section{Introduction}

Composting is an aerobic solid-state fermentation process in which different organic substances are converted into more stable compounds via microorganisms [1]. Composting of municipal solid wastes (MSW) is an environmentally friendly [2] and sustainable option for the treatment of organic fraction [3]. Moreover, it is an important technology in developing countries, where wastes generally have high

*e-mail: hakancelikten@kafkas.edu.tr wet organic matter [4]. Composting of organic waste is an important strategy for reducing methane emissions from landfills and for maintaining landfill occupancy. Compost is obtained at the end of the process, which contributes to the improvement of the physical, chemical, and microbiological properties of the soil [1]. Decomposition of mechanically separated organic fraction (MSOF) of municipal solid waste significantly contributes to the production of volatile compounds (VCs) [5]. Composting processes, which represent a complex mixture of gases and volatile organic compounds (VOC), cause odors [6] and these odorants cause serious concern due to their disturbing nature for the residents [7]. At the same time, the composting 
process causes greenhouse gas emissions such as nitrous oxide $\left(\mathrm{N}_{2} \mathrm{O}\right)$ and methane $\left(\mathrm{CH}_{4}\right)[8,9]$. For this reason, it is very important to treat a wide variety of VOCs and odorous gases emitted from these facilities in terms of public health and air pollution control with appropriate treatment technologies.

Biological treatment techniques for $\mathrm{VOC}$ and odor control have gained enormous popularity [10] and have proven to be effective technologies for the treatment of polluted air [11], when compared to traditional physical and chemical removal methods. Nowadays, several bioreactor designs such as biofilters, bio-trickling filters and bio-wet scrubbers are available for waste gas treatment. The most popular and the oldest bioreactor configuration is the classical biofilter that has been in use for the past 30 years [11]. Biofilters can be regarded as an environmentally friendly treatment technique [12] for the control of VOCs when compared to conventional treatment techniques such as incineration and adsorption [13] due to their lower cost and no hazardous waste production. Biofilters are porous bioreactors in which degrading organisms are fixed on the packing material [10]. Waste gas passes through the porous medium inside the packing material and the pollutants are dispersed inside the biofilm, where microflora makes biological oxidation [14]. Biodegradation of VOCs/ odorous compounds takes place within the biofilm [10]. Therefore, the microorganism population is from one of the most important parameters in the design and operation of the biofilters.

The detailed investigation of the basic principles such as pollutant type and concentration, packing material, moisture content, idle bed retention time, temperature and pressure losses makes it possible to determine optimum operating conditions of biofilters and to design more efficient reactors in waste gas treatment. However, studies on biological processes, in which waste gases are removed by microorganisms living in the biofilm layer, are usually carried out in laboratory [15-19] and pilot scale [20] bacteria/fungus populated biofilter configurations. In the majority of these studies, the microbial flora was responsible for the treatment of a single pollutant. There are very few studies on the bacterial population composition in the full-scale biofilter units used for the treatment of waste gas emissions [21-23]. Inoculation of specialized (adapted) microorganisms in bioreactors may also be useful in some applications [24], as prolonged sustainability of microbial activity is a significant problem.

The aim of this study was to focus on determining the prevailing microbial communities in the biofilter unit used for eliminating volatile organic compounds at a municipal solid waste composting facility.

\section{Experimental Procedures}

\section{Composting Plant and Process}

The Kemerburgaz Compost and Recovery Facility, in operation since 2001, was built in an open area of $320.000 \mathrm{~m}^{2}$. Approximately 700 tons of domestic solid waste is transferred to the Kemerburgaz compost plant daily. 400 tons of the waste is used for composting, while the remaining amount is manually separated and directed to the recovery unit [25]. The facility consists of four different units, including compost recovery, granule, pet-burlap and refuse-derived fuel (RDF). A physical pre-treatment is applied to the wastes by passing through a $\varnothing 80 \mathrm{~mm}$ screen, and the sub-screen material is passed through a magnetic separator and then the remaining portion is sent to the composting unit. The applied composting method is an aerobic composting technique known as tunnel composting. The compost is obtained as a final product after 8 weeks of aerobic fermentation process by processing the waste, including vegetable and fruit wastes, branch wastes, and organic wastes in a tunnel-type composting reactor [26]. The waste gases produced in the fermentation unit are treated in an open bed biofilter unit with 3 open bed biofilter units. The area of this study is shown in Fig. 1.
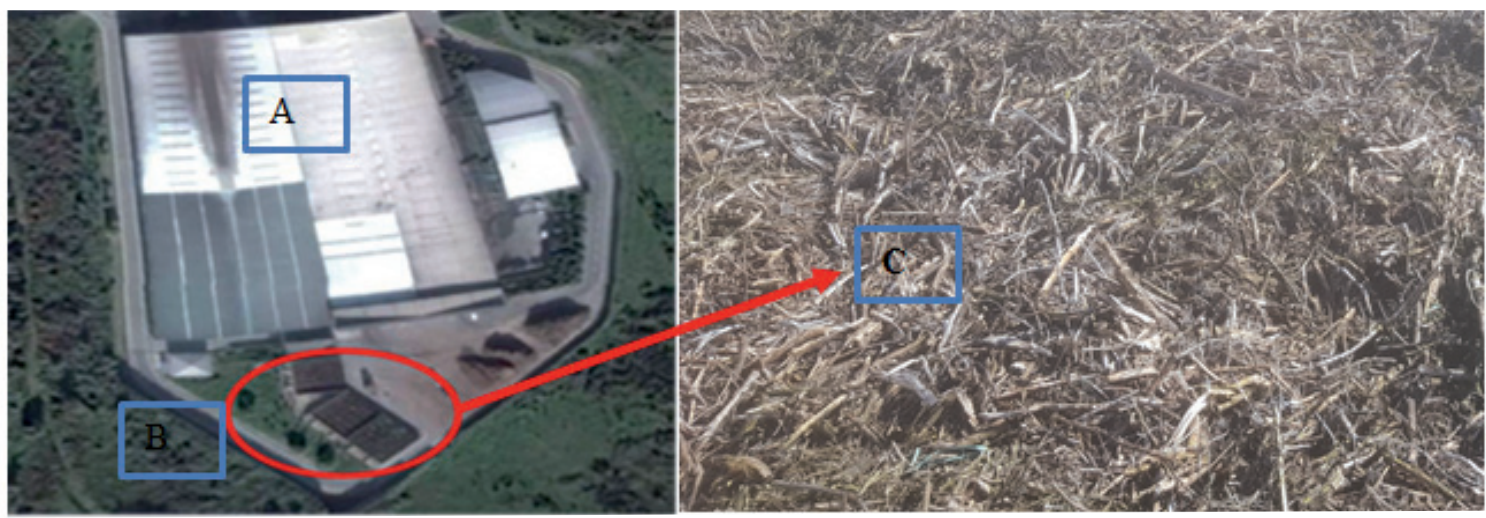

Fig. 1. A) Layout of composting and recovery plant ( $41^{\circ} 13^{\prime} \mathrm{N}$ and $\left.28^{\circ} 49^{\prime} \mathrm{E}\right)$, B) Biofilter units, and C) Packing materials in the biofilter unit (woodchips). 


\section{Full-Scale Woodchip Biofilter and Sampling Points}

The released odourous compounds are collected through a fan and transferred by a piping system to the biofilters. The approximate flowrate is 20,000-25,000 $\mathrm{m}^{3} /$ hour. The approximate contact time through the packing material is $50-100$ seconds. Each biofilter unit has dimensions of $20 \times 20 \times 2 \mathrm{~m}$ (width $\mathrm{x}$ length $\mathrm{x}$ height). Yasuda et. al. [23] took samples from packing material to determine the bacterial community at three different depths, ranging from 50 to $140 \mathrm{~cm}$ in a full-scale mineral fiber biofilter used to treat compost livestock emissions. Friedrich et. al. [27] studied the bacterial diversity at an industrial biofilter in an animal-rendering plant and samples were taken from four different depths $(20,60,110$ and $160 \mathrm{~cm})$ at a single location of the biofilter. In this study, samples were collected from $0.2 \mathrm{~m}$ depth over the packing material at 5 different points. The sampling points (A, B, C, D, E) are shown in Fig. 2.

Wooden packing materials have some disadvantages such as deterioration, poor nutrient quality and pressure losses [28]. Therefore, the woodchip material needs to be renewed approximately every two years [29]. In our study, the wooden packing materials were replaced on August 2017. No inoculation was applied to the biofilter because organic-based packing material was utilized and our primary aim was to determine the VOC adapted bacterial community. Thus, the packing material samples were collected three months after replacement (November 2017) in order to provide enough time for the bacteria to adapt to the VOC mixture. At the same time, VOC emissions from the composting process were qualitatively identified.

\section{Acquiring Pure Bacteria Cultures and DNA Extraction}

Bacteria were estimated from suspensions obtained from $10 \mathrm{~g}$ of a sample of the packing material at each sampling point (A, B, C, D, E) by mixing in a $0.85 \%$ $90 \mathrm{~mL}$ physiological saline solution (dissolve $0.85 \mathrm{~g}$ $\mathrm{NaCl} 100 \mathrm{~mL}$ distilled water). The suspensions were shaken at $150 \mathrm{rpm}$ for 30 minutes at room temperature [30] and the resulting solutions were diluted to $10^{-1}$, $10^{-2}, 10^{-3}, 10^{-4}, 10^{-5}$, and $10^{-6}$. Solid nutrient agar media were prepared and laid in petri dishes. Agar medium was prepared utilizing $15 \mathrm{~g} \mathrm{~L} \mathrm{~L}^{-1}$ Nutrient Broth No. 2 (Sigma-Aldrich) and $10 \mathrm{~g}$ of bacteriological agar (Oxoid). $250 \mu \mathrm{L}$ of the prepared dilution series was aseptically spread on the solid nutrient agar plate and the plates were incubated at $36^{\circ} \mathrm{C}$ for 24 hours. The different colonies obtained at the end of incubation were completely separated from each other and each was covered on a solid agar. A total of 21 isolated colonies (A: 6, B: 5, C: 4, D: 3, E: 3) were obtained from the sampling points. The acquired isolated colonies were cultivated in $40 \mathrm{~mL}$ of liquid medium (Nutrient Broth No. 2) and subjected to the same incubation period.

Bacterial cultures grown in liquid media were vortexed for 3 minutes in $1.5 \mathrm{~mL}$ ependorfs and the supernatant was centrifuged for 5 minutes at $7000 \mathrm{rpm}$ [31]. The resulting pellet was extracted using

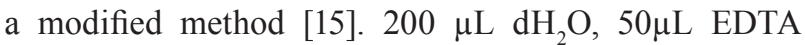
$(0.5 \mathrm{M}), 10 \mu \mathrm{L}$ proteinase $\mathrm{K}\left(10 \mathrm{mg} \mathrm{mL}^{-1}\right), 10 \mu \mathrm{L} 1 \mathrm{M}$ Tris- $\mathrm{HCl}[\mathrm{pH} 8.0]$ ve $5 \mu \mathrm{L} 5 \mathrm{M} \mathrm{NaCl}$ were included on the cell pellets and the mixture was vortexed for 5 minutes. At the end of this process, $10 \mu \mathrm{L} 20 \%$ SDS (sodium dodecyl sulfate) was added to the mixture and the samples were shaken upside down every 10 minutes for a 30 -minute duration at $65^{\circ} \mathrm{C}$ in a water bath. $\mathrm{A} \mathrm{Ph}$ enol:chloroform:isoamylalcohol (25:24:1 v:v:v) mixture was added to the samples. After centrifuging for $5 \mathrm{~min}$ at $13,000 \mathrm{rpm}$, the supernatant was transferred to $2 \mathrm{~mL}$ of new ependorf tubes. $3 \mathrm{M} \mathrm{NaOAc}$ with a volume of $1 / 10$ of supernatant and absolute ethanol of twice the supernatant volume was included to the ependorfs and incubated at $-20^{\circ} \mathrm{C}$ for 24 hours. At the end of this period, samples were centrifuged at $13,000 \mathrm{rpm}$ for $10 \mathrm{~min}$, the supernatant was removed and the pellet was dried. The dried pellet was dissolved by the addition

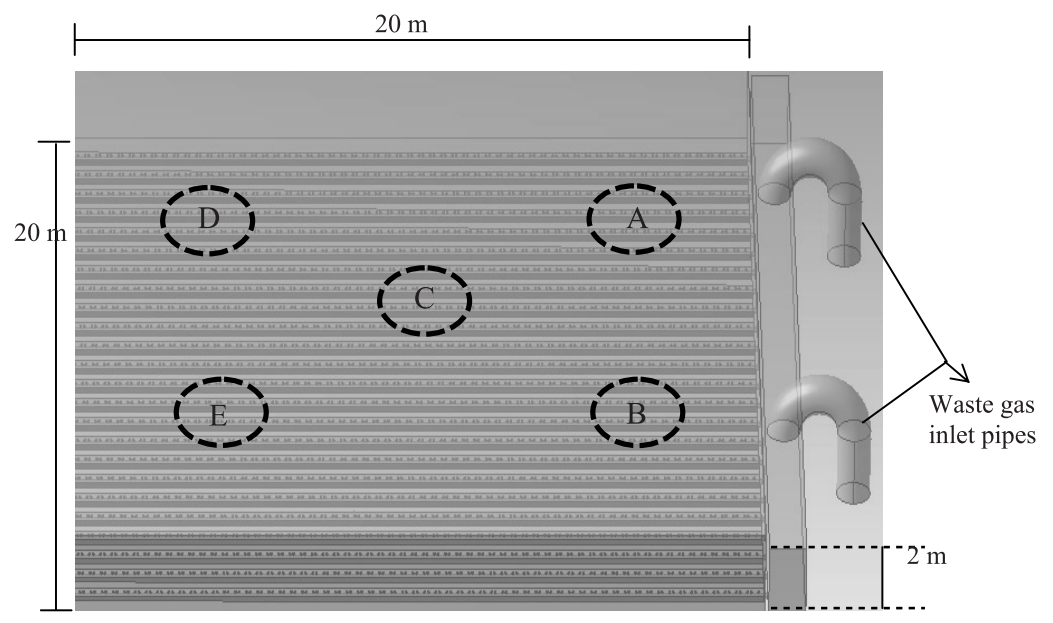

Fig. 2. Scheme of the full-scale biofilter unit and sampling points. 
of $200 \mu \mathrm{L}$ of $\mathrm{dH}_{2} \mathrm{O}$. $0.3 \mathrm{M} \mathrm{NaOAc}$ with $1 / 10$ volume of the solution, and $440 \mu \mathrm{L}$ ethanol was included to the dissolved pellet, and incubation, centrifuge, and drying was applied as described above. Finally, the dried pellet was dissolved with $100 \mu \mathrm{L}$ of $\mathrm{dH}_{2} \mathrm{O}$. The concentration of the DNA obtained was determined by $1 \%$ (wt/vol) agarose gel electrophoresis in $1 \mathrm{X}$ TAE (40 mMTris, $5 \mathrm{mM}$ sodium acetate, $1 \mathrm{mM}$ EDTA $\mathrm{pH}$ 7.8).

\section{PCR Amplification of 16S rDNA}

All of the purified DNAs were amplified using two universal bacterial primers $27 \mathrm{~F}$ 5'- GAG TTT GGC TCA-3' and 1385R 5'-GGTGTGT (A/G) CAAGGCCC-3'. PCR amplification reaction was performed using a TC-E-96G Model, GenePro Thermal Cycler (Bioer Technology Co., Ltd) at a final volume of $50 \mu \mathrm{L}$ containing $5 \mu \mathrm{L} 10 \times$ PCR buffer $(25 \mathrm{mM}$, containing $\left.\mathrm{MgCl}_{2}\right), 1 \mu \mathrm{L}$ dNTP mix $(10 \mathrm{mM}), 5 \mu \mathrm{L}$ forward and $5 \mu \mathrm{L}$ reverse primers, $1 \mu \mathrm{L}$ template DNA, $500 \mathrm{U}$ Taq $0.5 \mu \mathrm{L}$ DNA polymerase, and distilled water. The amplification program was as follows: one initial denaturation cycle consisting of $94^{\circ} \mathrm{C}$ for $5 \mathrm{~min}$, followed by 35 cycles consisting of $94^{\circ} \mathrm{C}$ for $1 \mathrm{~min}$ (denaturation), $58^{\circ} \mathrm{C}$ for $1 \mathrm{~min}$ (annealing), and $72^{\circ} \mathrm{C}$ for $1 \mathrm{~min}$ (extension), and a final extension step consisting of $72^{\circ} \mathrm{C}$ for $5 \mathrm{~min}$.

The final PCR products were examined by agarose gel electrophoresis and stained with ethidium bromide for visualization upon UV illumination $[15,32]$. Agarose gel electrophoresis was carried out in a horizontal electrophoresis tank (Wealtec, Elite 300 Plus, Made in Talwan). The electrophoresis was run for $1 \mathrm{~h}$ and 90 V. Briefly, PCR products were carried out $1 \%(\mathrm{w} / \mathrm{v})$ agarose gels in $1 \mathrm{X}$ TAE. DNA was viewed after UV transillumination, and agarose gel images were stored using the 'Bio-ImagingSystem.'

\section{Sequence Analysis}

Following the confirmation of a prospering PCR reaction by agarose gel electrophoresis, the PCR products were purified with a PCR purification kit (AgencourtAMPure XP) following the instructions given by the manufacturer (Beckman CoulterA63881) using a DynaMagTM-96 side magnet. Purified PCR products $(2 \mu \mathrm{L})$ were added in a reaction mixture containing $0.5 \mu \mathrm{L}$ Big Dye, $2 \mu \mathrm{L} 5 \mathrm{X}$ sequencing buffer, $10 \mu \mathrm{L}$ DEPC-treated water and $0.5 \mu \mathrm{L}$ from each primer (27f and 1385r). These mix reactions were performed using a thermal cycler with the following thermo cycling program: one cycle $96^{\circ} \mathrm{C}$ for $1 \mathrm{~min}$, followed by one cycle $96^{\circ} \mathrm{C}$ for $10 \mathrm{sec}, 25$ cycles $50^{\circ} \mathrm{C}$ for $25 \mathrm{sec}$, and $60^{\circ} \mathrm{C}$ for $4 \mathrm{~min}$. Sequence PCR samples were purified with a ZR-96 DNA sequencing clean-up kit (Zymo Research Corp.). The capillary electrophoresis application of purified sequence products were accomplished using an ABI 3130 (Applied Biosystems Inc.) capillary electrophoresis device. Multiple alignment analyses were conducted using BioEdit v7.0.5. The determined nucleotide and translated amino acid sequences were compared with those deposited in the National Center for Biotechnology Information (NCBI) database by a BLASTN search $[15,23,31]$. The nucleotide sequence data reported in this study was deposited in the NCBI nucleotide databases under the accession numbers MH400169 to MH400185.

\section{Results and Discussion}

\section{VOC Emissions of the Composting Process}

Diverse VOC emissions are produced during the composting of municipal solid wastes. Those compounds vary depending on the composting method and amount and type of waste being processed. Schlegelmilchet et al. [7] stated that the odors in the composting plants are released from processes such as storage, rotation, screening, and cleaning. There are various odor sources in composting plants such as material handling and transfer, aerating composting, stocking, etc. [33]. Odors are by-products inherent to the composting process regardless of the initial organic material or process conditions [9]. These odors are caused by certain inorganic gases (such as ammonia and hydrogen sulfide) and organic compounds that are released during the biological degradation of organic residues [34]. Odors from composting facilities clearly contribute to the surrounding environment and in most cases result in social complications resulting from the closure of the installation or the implementation of preventive measures [3]. Therefore, studies have focused on the identification and quantification of volatile organic compounds emitted from composting plants in recent years. Organic acids, alcohols, and sulfides are the main compounds resulting from the composting of municipal solid wastes (MSW), while composting of garden wastes results primarily in terpenes (i.e., natural compounds emitted from raw materials) and lower levels of alcohols, ketones and benzenes as a result of biological degradation [35]. Maulini-Duran et al. [36] classified the emitted pollutants as alcohols, esters, furans, ketones, aliphatic hydrocarbons, aromatic hydrocarbons, aldehydes, halogenated compounds, nitrogen-containing compounds, sulfur-containing compounds, and terpenes from unseparated municipal solid waste (MSW) and organic fraction separated municipal solid waste (OFMSW). It was reported that terpenes are the main VOC family. Ten of the 10 identified VOC species (Styrene, 2-Pentanone, $\alpha$-pinene, $\beta$-pinene, Limonene, Dimethyl disulfide, pyridine, toluene, xylene and decane) were found in the studied composting processes. Volatile sulfur compounds such as hydrogen sulfide $\left(\mathrm{H}_{2} \mathrm{~S}\right)$, methyl mercaptan (MM), dimethyl sulfide (DMS), dimethyl disulfide (DMDS), and carbon disulfide $\left(\mathrm{CS}_{2}\right)$ are formed during kitchen composting [37]. Gallegoet et al. [38] detected a wide 
variety of VOC emissions, including alkanes, aromatic hydrocarbons, alcohols, ketones, halocarbons, aldehydes, esters, acids, terpenes, organosulfides, ethers, and furans in a mechanical-biological waste composting tunnel of an MSW composting facility with 245,000 tons/year capacity (organic fraction 85,000 tons/year) in Barcelona. Mao et al. [39] studied odorous species in three different composting plants used for processing vegetable, fruit, garden, and household food wastes in Taiwan. They identified 29 compounds including ammonia, amines, acetic acid, dimethyldisulfide, hydrocarbons (penten, hexen, benzene, toluene, ethylbenzene, p-xylene, styrene, o-xylene, ketones (acetone and butanone), esters (methyl acetate and ethyl acetate), terpenes ( $\alpha$-pinene, $\beta$-pinene, limonene and $\mathrm{p}$-simen). Komiliset et al. [40] identified and quantified selected 25 VOC species released during the composting of three organic MSW components (food waste, garden waste, and mixed paper waste) and their mixtures in a closed container. Although the relative abundance of VOCs emitted from the MSW composting process vary in different studies, the main compositions generally contain terpenes, aliphatic hydrocarbons, aromatic hydrocarbons, alcohols, ketones, and esters [8, 41]. The waste gas VOC composition of this study is present elsewhere [26]. Benzene, toluene, ethylbenzene, o-xylene styrene, and 1,1-dichloroethene were predominantly detected among the determined species [26].

\section{Identifying the Bacterial Community}

The dominant bacterial community that is responsible for the treatment of VOC mixtures has been identified in a full-scale biofilter unit filled with wood chips. Purification and DNA extraction was performed for isolated cultures from the packing material $(10 \mathrm{~g}$ sample for each sampling point) at five different sample collection points (Fig. 2). A total of 21 pure cultures were obtained at sampling points $\mathrm{A}, \mathrm{B}, \mathrm{C}, \mathrm{D}$, and $\mathrm{E}$, with the numbers $6,5,4,3,3$, respectively. The DNA from these cultures was used to amplify $16 \mathrm{~S}$ rDNA genes. Strong amplification of the 16s rDNA genes was observed at the end of three months after the biofilter unit started to operate. Woodchip samples suggest that there was little or no inhibition of PCR by DNA extracts at the end of 90 days. The images of PCR products were examined by agarose gel electrophoresis at about 1300 bp (Fig. 3).

High-quality sequences were achieved for the forward (27f) and reverse (1385r) primers in all samples except A2, B1, B2, and E2. Multiple alignment analyses were conducted using BioEdit v7.0.5. The determined nucleotide and translated amino acid sequences were compared with those deposited in the National Center for Biotechnology Information (NCBI) database by a BLASTN search. The nucleotide sequence data reported in this study were stored in the NCBI nucleotide databases under the accession numbers MH400169 to MH400185 (Table 1).

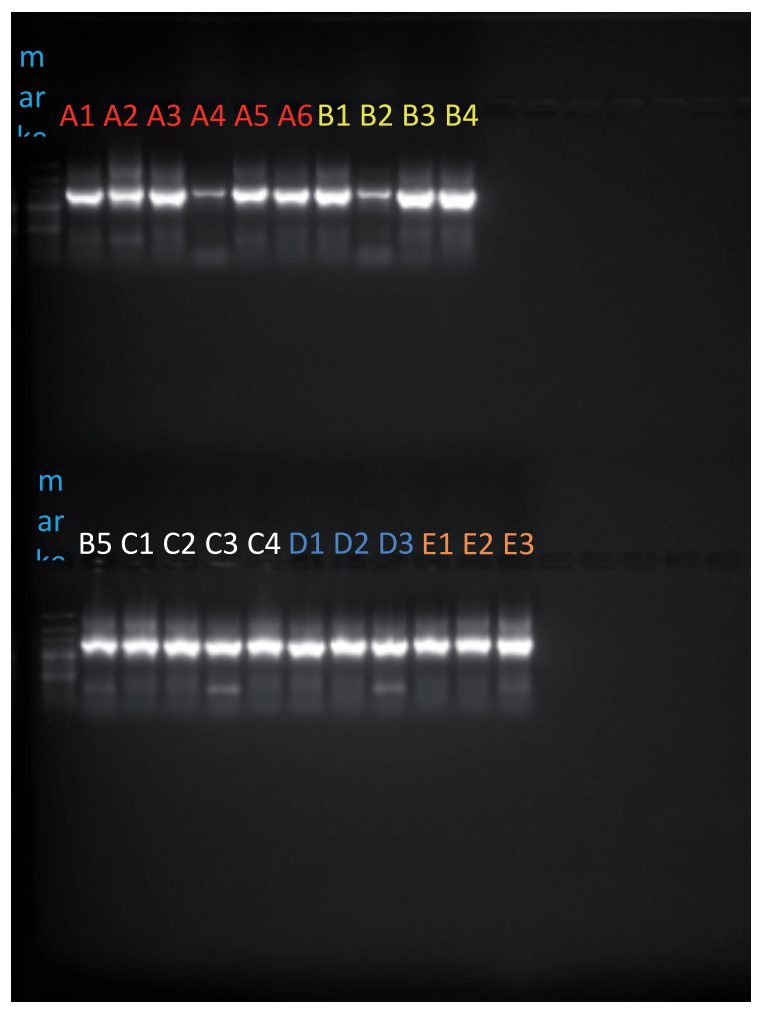

Fig. 3. Agarose gel images of the samples from biofiltration processes filled with woodchips.

Although the strains could not be identified for A2, B1, B2, and E2 samples due to low-quality sequences (600-800 bp), approximate similarities for the other 17 samples were between $97 \%$ and $99 \%$. Only the A4 sample had a similarity relationship of $84 \%$ (Solibacillus silvestris). Bacillaceae and Enterobacteriaceae families had dominance of 53\% and 47\%, respectively (Fig. 4).

Bacillus is a strain of gram-positive bacteria and a member of the phylum Firmicutes, and the genus can obligate aerobes or facultative anaerobes. Bacillus strains are used in many medical, agricultural, and industrial processes because the possess the ability of their wide range of physiological characteristics [42]. Enterobacter is a genus of common gram-negative, facultative anaerobic, rod-shaped, non-spore-forming bacteria of the family Enterobacteriaceae. There are several reports that the members of Enterobacter get possession of the ability to form biofilms [43]. In biofilters, anaerobic zones may occur as a result of microorganism deaths due to environmental conditions (insufficient nutrients, humidity, temperature and variable $\mathrm{pH}$, etc.) and compaction of the packing material layer over time. Therefore, the dominance of bacterial strains that can adapt to conditions where the oxygen amount is a limiting factor is vital in sustaining continuous pollutant removal. In this study, experimental results indicate that the bacterial genus of Enterobacter cloacae (MH400169; MH400170; MH400182; MH400184), Enterobacter ludwigii (MH400172) and Serratia marcescens (MH400176; 
Table 1. The most closely interrelated sequences obtained in the NCBI for the agarose gel bands from bacterial 16S rDNA genes.

\begin{tabular}{|c|c|c|c|c|}
\hline Sample Band & Bacteria Species & $\begin{array}{l}\text { Accession } \\
\text { Number }\end{array}$ & Reference species and Accession Number ${ }^{(X)}$ & Ident $(\%)$ \\
\hline A1 & Enterobacter cloacae & MH400169 & Enterobacter cloacae -KY524292.1 & 99 \\
\hline A2 & - & Unidentified & - & - \\
\hline $\mathbf{A 3}$ & Enterobacter cloacae & MH400170 & Enterobacter cloacae - HM162426.1 & 98 \\
\hline A4 & Solibacillus silvestris & MH400171 & Solibacillus silvestris - KX768291.1 & 84 \\
\hline A5 & Enterobacter ludwigii & MH400172 & Enterobacter ludwigii - FR820478.2 & 97 \\
\hline \multirow{5}{*}{ A6 } & \multirow{5}{*}{ Bacillus paralicheniformis } & \multirow{5}{*}{ MH400173 } & Bacillus paralicheniformis - MG651522.1 & 99 \\
\hline & & & Bacillus sp. - MF765301.1 & 99 \\
\hline & & & Bacillus licheniformis - KP245791.1 & 99 \\
\hline & & & Bacillus licheniformis - HE801969.1 & 99 \\
\hline & & & Bacillus licheniformis - JN166722.1 & 99 \\
\hline B1 & - & Unidentified & - & - \\
\hline B2 & - & Unidentified & - & - \\
\hline B3 & Bacillus sp. & & Bacillus sp. - KX507087.1 & 99 \\
\hline \multirow{4}{*}{ B4 } & \multirow{4}{*}{ Bacillus licheniformis } & MH400174 & Bacillus licheniformis - СР026673.1 & 98 \\
\hline & & \multirow{3}{*}{ MH400175 } & Bacillus sp. - СР022874.1 & 98 \\
\hline & & & Bacillus licheniformis - СР022477.1 & 98 \\
\hline & & & Bacillus licheniformis - СР021677.1 & 98 \\
\hline B5 & Serratia marcescens & MH400176 & Serratia marcescens - KX343948.1 & 99 \\
\hline C1 & Bacillus cereus & MH400177 & Bacillus cereus - KT153601.1 & 99 \\
\hline \multirow{2}{*}{$\mathbf{C 2}$} & \multirow{2}{*}{ Bacillus sp. } & \multirow{2}{*}{ MH400178 } & Bacillus sp. - KM596515.1 & 98 \\
\hline & & & Bacillus sp. - HM567093.1 & 98 \\
\hline \multirow{3}{*}{$\mathbf{C 3}$} & \multirow{3}{*}{ Serratia marcescens } & \multirow{3}{*}{ MH400179 } & Serratia sp.- KY780228.1 & 99 \\
\hline & & & Serratia marcescens - JX103454.1 & 99 \\
\hline & & & Serratia marcescens - JX103452.1 & 99 \\
\hline $\mathrm{C4}$ & Bacillus cereus & MH400180 & Bacillus cereus - KT153601.1 & 99 \\
\hline D1 & Bacillus cereus & MH400181 & Bacillus cereus - KT153601.1 & 99 \\
\hline \multirow{2}{*}{ D2 } & \multirow{2}{*}{ Enterobacter cloacae } & \multirow{2}{*}{ MH400182 } & Enterobacter cloacae - KY524292.1 & 97 \\
\hline & & & Enterobacter cloacae - HM162426.1 & 97 \\
\hline \multirow{2}{*}{ D3 } & \multirow{2}{*}{ Serratia sp. } & \multirow{2}{*}{ MH400183 } & Serratia sp. - KY780228.1 & 99 \\
\hline & & & Serratia marcescens - JX103452.1 & 99 \\
\hline E1 & Enterobacter cloacae & MH400184 & Enterobacter cloacae - KY524292.1 & 99 \\
\hline $\mathbf{E 2}$ & - & Unidentified & - & - \\
\hline $\mathbf{E 3}$ & Bacillus sp. & MH400185 & Bacillus sp. - KJ948672.1 & 99 \\
\hline
\end{tabular}

${ }^{\mathrm{x}}$ Strains determined according to NCBI Max Score

MH400179; MH400183) from the Enterobacteriaceae family, and Solibacillus silvestris (MH400171), Bacillus licheniformis (MH400175), Bacillus cereus (MH400177; MH400180; MH400181) and Bacillus paralicheniformis (MH400173) from the bacterial genus of Bacillaceae family played key roles in the degradation of VOC species such as benzene, toluene, ethyl benzene, o-xylene styrene, 1,1-dichloroethane, etc. [26].

When the VOC reduction capacities of the biofilters are evaluated, mixtures such as propanal, methyl isobutyl ketone, toluene and hexanol, and bacterial biofiltration were determined to have higher elimination capacities 


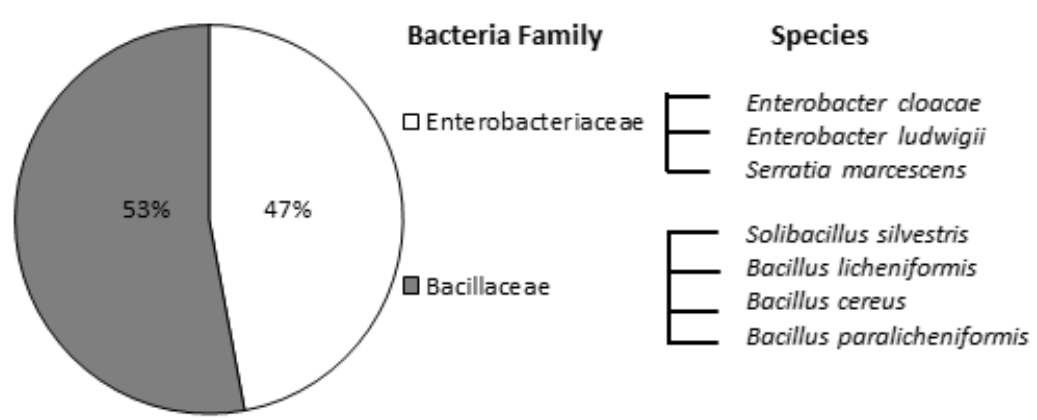

Fig. 4. Distribution of bacterial community biofilter packing material (\%).

(EC) and mineralization ratios than fungal biofiltration [44]. The combination of fungal and bacterial biofilter (F\&B-BF) exhibited higher performance than conventional biofilters for a single species contaminant such as toluene [16]. In the open literature, bacterial or fungal populations in the biofilters were identified for mostly single pollutant components or with a few numbers of VOC mixtures in laboratory, pilot or fullscale plants.

Prenafeta-Boldúet et al. [45] treated toluene, ethylbenzene, and p-xylene, including waste gas at a laboratory-scale biofilter. The biofilter was inoculated with degrading liquid enrichment culture. The dominant fungi strain was Ribotypes. Zhaiet et al. [16] found that Proteobacteria (47.96\%), Actinobacteria (31.16\%), and Firmicutes (79.81\%) bacteria phylum dominated steady-state bacteria, fungi/bacteria $\left(\mathrm{NH}_{4}^{+}\right)$, and fungi/ bacteria $\left(\mathrm{NO}_{3}^{-}\right)$biofilter, used in toluene treatment. Thanera (18.10\%), Alicyclobacillus (10.67\%), and Alicyclobacillus bacteria strains were predominant in those biofilters, respectively. Cheng et al. [18] treated toluene in fungi/bacteria, fungi, and bacteria-based biofilters and identified predominant bacterial strains were Burkholderiales (27.64\%), Lactococcus (22.5\%), and Burkholderiales (41\%), respectively. Those strains were followed by Lactococcus (8.33\%), Clostridium (15.73\%), and Pandoraea (7.73\%), respectively. Yasuda et al. [21] determined that the population of ammoniaoxidizing bacteria mainly belongs to Nitrosomonas europaea lineage and Nitrosospira cluster 3 in the fullscale mineral fiber biofilter, where odors of livestock manure composting are treated. Similarly, Tsang et al. [46] studied the biofiltration of ammonia and typically identified ammonia oxidizing Nitrosomonas europaea bacteria strain. Friedrich et al. [42] associated 90.5\% of 16S rDNA with Proteobacteria and Bacteroidetes Phylum sequences in a biofilter of an animal-rendering plant. Alpha, beta, and gamma proteobacteria were calculated as $22.1 \%, 17.6 \%$, and $18.6 \%$, respectively. Small sections were accociated with Actinobacteria (2.0\%), Firmicutes and Verrucomicrobia (1.0\% for both), and Deltaproteobacteria and Thermomicrobia $(0.5 \%$ for each).

Bacteria and fungi communities play an active role in the composting process. At the beginning of the composting process, organic acid-producing mesophilic bacterial genus such as Lactobacillus spp. and Acetobacter spp., in the subsequent thermophilic step Bacillus spp., and Actinobacteria were reported to be predominant [47]. This study revealed that Firmucutes and Proteobacterium bacterium phylum dominated the process. The dominant genus of Firmicutes phyla were Bacilluscereus (22\%), Bacillus licheniformis (14\%), Bacillus paralicheniformis (7\%), Solibacillus silvestris (7\%), and the dominant genus of Proteobacteria phyla were Enterobacter cloacae (29\%), Serratia marcescens (14\%) and Enterobacter ludwigii (7\%). These results demonstrate that the predominant bacterial strains in the biofilter unit filled with woodchips have the ability to eliminate a wide variety of VOCs as energy and carbon sources, and thus have an impact on pollutant uptake. In addition, the determined strains have shown that despite the anaerobic zones in the biofilter bed, they can continue their vital activities and represent the main bacterial community responsible for the treatment of similar biological processes.

\section{Conclusions}

This study consists of determining and evaluating predominant bacterial strains in a full-scale biofilter unit, which is used for treating VOC mixture, without any inoculation. The major bacteria family was determined as Bacillaceae and Enterobacteriaceae. Bacillus cereus, Bacillus licheniformis, Bacillus paralicheniformis, Solibacillussilvestris, Enterobacter cloacae, Serratiamarcescens and Enterobacter ludwigii have been identified as predominant bacterial strains in the treatment of mixed VOCs. In biofilter processes, the biodegradation of VOC/odorous substances takes place in the biofilm layer attached to the filling material. Various environmental factors (temperature, $\mathrm{pH}$, moisture content, oxygen content, etc.) in the biofilm layer, which is the habitat for bacterial populations, affect biological activity. For this reason, it can be said that bacterial species in the filling material have an active role in the treatment of different VOCs originating from the compost plant. As this study was conducted in 
full scale, the identified bacterial strains are capable of forming biofilm in the treatment of VOCs. The results of this work will contribute to the understanding of the diversity of microbial communities in similar biofilter processes fed with a similar waste gas mixture covered with organic packing material (woodchips, bark, root etc.). Additionally, inoculation of the bacterium strains identified in the study, especially with the biofilter process (laboratory, pilot, or full scale) filled with inorganic packing material, will allow us to reduce the acclimatization period and improve the efficiency of waste gas removal.

\section{Acknowledgements}

The authors would like to thank ISTAÇ Inc. for their administrative and technical support during this study. The assistance of Dr. Cem Öziç and Dr. Orhan Uluçay from Kafkas University, Turkey, is also greatly acknowledged by the authors.

\section{Conflict of Interest}

The authors declare no conflict of interest.

\section{References}

1. SÁNCHEZ Ó.J., OSPINA D.A., MONTOYA S. Compost supplementation with nutrients and microorganisms in composting process. Waste Management. 2017.

2. JARA-SAMANIEGO J., PÉREZ-MURCIA M.D., BUSTAMANTE M.A., PÉREZ-ESPINOSA A., PAREDES C., LÓPEZ M., LÓPEZ-LLUCH D.B., GAVILANESTERÁN I., MORAL R. Composting as sustainable strategy for municipal solid waste management in the Chimborazo Region, Ecuador: Suitability of the obtained composts for seedling production. Journal of Cleaner Production. 141, 1349, 2017.

3. COLÓN J., CADENA E., POGNANI M., BARRENA R., SÁNCHEZ A., FONT X., ARTOLA A. Determination of the energy and environmental burdens associated with the biological treatment of source-separated municipal solid wastes. Energy \& Environmental Science. 5 (2), 5731, 2012.

4. BOLDRIN A., ANDERSEN J.K., MØLLER J., CHRISTENSEN T.H., FAVOINO E. Composting and compost utilization: accounting of greenhouse gases and global warming contributions. Waste Management \& Research. 27 (8), 800, 2009.

5. MUSTAFA M.F., LIU Y., DUAN Z., GUO H., XU S., WANG H., LU W. Volatile compounds emission and health risk assessment during composting of organic fraction of municipal solid waste. Journal of hazardous materials. 327, 35, 2017.

6. AVIDOV R., SAADI I., KRASSNOVSKY A., HANAN A., MEDINA S., RAVIV M., CHEN Y., LAOR Y. Composting municipal biosolids in polyethylene sleeves with forced aeration: Process control, air emissions, sanitary and agronomic aspects. Waste Management. 67, 32, 2017.

7. SCHLEGELMILCH M., STREESE J., BIEDERMANN W., HEROLD T., STEGMANN R.Odour control at biowaste composting facilities. Waste Management. 25 (9), $917, \mathbf{2 0 0 5}$

8. SCAGLIA B., ORZI V., ARTOLA A., FONT X., DAVOLI E., SANCHEZ A., ADANI F.Odours and volatile organic compounds emitted from municipal solid waste at different stage of decomposition and relationship with biological stability. Bioresource technology. 102 (7), 4638, 2011.

9. CERDA A., ARTOLA A., FONT X., BARRENA R., GEA T., SÁNCHEZ A. Composting of food wastes: Status and challenges. Bioresource technology. 2017.

10. MUDLIAR S., GIRI B., PADOLEY K., SATPUTE D., DIXIT R., BHATT P., PANDEY R., JUWARKAR A., VAIDYA A. Bioreactors for treatment of VOCs and odours - a review. Journal of environmental management. 91 (5), 1039, 2010

11. KENNES C., RENE E.R., VEIGA M. C. Bioprocesses for air pollution control. Journal of Chemical Technology and Biotechnology. 84 (10), 1419, 2009.

12. VIKRANT K., KIM K.-H., SZULEJKOJ. E., PANDEY S. K., SINGH R.S., GIRI B.S., BROWN R.J.C., LEE S.-H. Bio-filters for the Treatment of VOCs and Odors. Asian Journal of Atmospheric Environment. 11 (3), 139, 2017.

13. LIU Q., LI M., CHEN R., LI Z., QIAN G., AN T., FU J., SHENG G.Biofiltration treatment of odors from municipal solid waste treatment plants. Waste Management. 29 (7), 2051, 2009.

14. BARBUSINSKI K., KALEMBA K., KASPERCZYK D., URBANIEC K., KOZIK V. Biological methods for odor treatment - A review. Journal of Cleaner Production. 152, 223, 2017

15. JUN Y., WENFENG X. Ammonia biofiltration and community analysis of ammonia-oxidizing bacteria in biofilters. Bioresource technology. 100 (17), 3869, 2009.

16. ZHAI J., WANG Z., SHI P., LONG C. Microbial community in a biofilter for removal of low load nitrobenzene waste gas. PloS one. 12 (1), e0170417, 2017.

17. BORIN S., MARZORATI M., BRUSETTI L., ZILLI M., CHERIF H., HASSEN A., CONVERTI A., SORLINI C., DAFFONCHIO D. Microbial succession in a compostpacked biofilter treating benzene-contaminated air. Biodegradation. 17 (2), 79, 2006.

18. CHENG Z., LU L., KENNES C., YU J., CHEN, J. Treatment of gaseous toluene in three biofilters inoculated with fungi/bacteria: microbial analysis, performance and starvation response. Journal of hazardous materials. 303, 83, 2016.

19. MOHAMED E.F., AWAD G., ANDRIANTSIFERANA C., EL-DIWANY A. I.Biofiltration technology for the removal of toluene from polluted air using Streptomyces griseus. Environmental technology. 37 (10), 1197, 2016.

20. CABROL L., POLY F., MALHAUTIER L., POMMIER T., LERONDELLE C., VERSTRAETE W., LEPEUPLE A.S., FANLO J.L., ROUX X. L. Management of microbial communities through transient disturbances enhances the functional resilience of nitrifying gas-biofilters to future disturbances. Environmental science \& technology. 50 (1), 338, 2015.

21. YASUDA T., KURODA K., HANAJIMA D., FUKUMOTO Y., WAKI M., SUZUKI K. Characteristics 
of the microbial community associated with ammonia oxidation in a full-scale rockwoolbiofilter treating malodors from livestock manure composting. Microbes and environments. 25 (2), 111, 2010.

22. KRISTIANSEN A., PEDERSEN K.H., NIELSEN P.H., NIELSEN L.P., NIELSEN J.L., SCHRAMM A. Bacterial community structure of a full-scale biofilter treating pig house exhaust air. Systematic and applied microbiology. 34 (5), 344, 2011.

23. YASUDA T., WAKI M., FUKUMOTO Y., HANAJIMA D., KURODA K., SUZUKI K. Characterization of the denitrifying bacterial community in a full-scale rockwoolbiofilter for compost waste-gas treatment. Applied microbiology and biotechnology. 101 (17), 6779, 2017.

24. CHENG Z., LU L., KENNES C., YE J., YU J., CHEN D., CHEN J. A composite microbial agent containing bacterial and fungal species: Optimization of the preparation process, analysis of characteristics, and use in the purification for volatile organic compounds. Bioresource technology. 218, 751, 2016.

25. YILDIZ Ş., ÖLMEZ E., KIRIŞ A. Kompost Teknolojilerive Istanbul'daki Uygulamaları (Kompost laştırma Sistemlerive Kompostun Kullanım Alanları Çalıştayı) (ss. 1-12). Istanbul. 2009.

26. ÇELIKTEN H., SARAL A., KUZU S.L. Volatile Organic Compound (VOC) Characterization of Municipal Solid Waste Composting Process Emissions. EURASIA Waste Management Symposium. 2018.

27. FRIEDRICH U., PRIOR K., ALTENDORF K., LIPSKI, A. High bacterial diversity of a waste gas-degrading community in an industrial biofilter as shown by a $16 \mathrm{~S}$ rDNA clone library. Environmental Microbiology. 4 (11), 721, 2002.

28. SHAREEFDEEN Z., HERNER B., WEBB D., WILSON S. Synthetic media biofilter eliminates hydrogen sulfide and other reduced sulphur compound odors. Proceedings of the Water Environment Federation. 2003 (7), 153, 2003.

29. BINDRA N., DUBEY B., DUTTA, A. Technological and life cycle assessment of organics processing odour control technologies. Science of the Total Environment. 527, 401, 2015.

30. LÓPEZ-GONZÁLEZ J.A., DEL CARMAN VARGASGARCÍA M., LÓPEZ M.J., SUÁREZ-ESTRELLA F., DEL MAR JURADO M., MORENO J. Biodiversity and succession of mycobiota associated to agricultural lignocellulosic waste-based composting. Bioresource technology. 187, 305, 2015.

31. HO K.-L., CHUNG Y.-C., TSENG C.-P. Continuous deodorization and bacterial community analysis of a biofilter treating nitrogen-containing gases from swine waste storage pits. Bioresource technology. 99 (8), 2757, 2008.

32. ÖZİÇ C., ARSLANYOLU M. Characterization of affinity tag features of recombinant Tetrahymenathermophila glutathione-S-transferase zeta for Tetrahymena protein expression vectors. Turkish Journal of Biology. 36 (5), 513, 2012.

33. CADENA E., COLÓN J., SÁNCHEZ A., FONT X., ARTOLA A.A methodology to determine gaseous emissions in a composting plant.Waste Management. 29 (11), 2799, 2009.
34. LÓPEZ R., CABEZA I.O., GIRÁLDEZ I., DÍAZ M.J. Biofiltration of composting gases using different municipal solid waste-pruning residue composts: Monitoring by using an electronic nose. Bioresource technology. 102 (17), 7984, 2011.

35. BUYUKSONMEZ F., EVANS J. Biogenic Emissions from green waste and comparison to the emissions resulting from composting part II: Volatile Organic Compounds (VOCs). Compost science \& utilization. 15 (3), 191. 2007.

36. MAULINI-DURAN C., ARTOLA A., FONT X., SÁNCHEZ A. Gaseous emissions in municipal wastes composting: effect of the bulking agent. Bioresource technology. 172, 260, 2014.

37. ZHANG H., LI G., GU J., WANG G., LI Y., ZHANG D. Influence of aeration on volatile sulfur compounds (VSCs) and $\mathrm{NH}_{3}$ emissions during aerobic composting of kitchen waste. Waste management. 58, 369, 2016.

38. GALLEGO E., ROCA F.J., PERALES J.F., SÁNCHEZ G., ESPLUGAS P. Characterization and determination of the odorous charge in the indoor air of a waste treatment facility through the evaluation of volatile organic compounds (VOCs) using TD-GC/MS. Waste management. 32 (12), 2469, 2012.

39. MAO I.-F., TSAI C.-J., SHEN S.-H., LIN T.-F., CHEN W.-K., CHEN M.-L. Critical components of odors in evaluating the performance of food waste composting plants. Science of the total environment. 370 (2-3), 323, 2006.

40. KOMILIS D.P., HAM R.K., PARK J.K. Emission of volatile organic compounds during composting of municipal solid wastes. Water research. 38 (7), 1707, 2004.

41. WEI Y., LI J., SHI D., LIU G., ZHAO Y., SHIMAOKA T. Environmental challenges impeding the composting of biodegradable municipal solid waste: A critical review. Resources, Conservation and Recycling. 122, 51, 2017.

42. NCBI. https://www.ncbi.nlm.nih.gov/books/NBK7699/ (2018, June 13) .

43. TAN W.-S., YUNOS N. Y. M., TAN P.-W., MOHAMAD N.I., ADRIAN T.-G.-S., YIN W.-F., CHAN K.-G. Freshwater-borne bacteria isolated from a Malaysian rainforest waterfall exhibiting quorum sensing properties. Sensors, 14 (6), 10527, 2014.

44. ESTRADA J.M., HERNÁNDEZ S., MUÑOZ R., REVAH, S.A comparative study of fungal and bacterial biofiltration treating a VOC mixture.Journal of hazardous materials. 250, 190, 2013.

45. PRENAFETA-BOLDÚ F.X., GUIVERNAU M., GALLASTEGUI G., VIÑAS M., DE HOOG G.S., ELÍAS A. Fungal/bacterial interactions during the biodegradation of TEX hydrocarbons (toluene, ethylbenzene and p-xylene) in gas biofilters operated under xerophilic conditions. FEMS microbiology ecology. 80 (3), 722, 2012.

46. TSANG Y.F., WANG Y., WANG H., YANG Y., ZHANG Y., CHUA H. Biodegradation of Ammonia in Biofiltration Systems: Changes of Metabolic Products and Microbial Communities. In Nitrification and Denitrification.InTech. 2017.

47. PARTANEN P., HULTMAN J., PAUlin L., AUVINEN P., ROMANTSCHUK M. Bacterial diversity at different stages of the composting process. BMC microbiology. 10 (1), 94, 2010. 